\title{
Distributive politics at play in Harare, Zimbabwe: case for housing cooperatives
}

\author{
Innocent Chirisa*, Elmond Bandauko and Nyasha Takawira Mutsindikwa
}

\author{
${ }^{*}$ Correspondence: \\ chirisa.innocent@gmail.com \\ University of Zimbabwe, \\ Harare, Zimbabwe
}

\begin{abstract}
This paper is a case in distributive politics (and hinges on land-based power dynamics) arguing that in the absence of state capacity to provide for housing, housing cooperatives have emerged and controlled largely by patronage. In this case, there is exclusion of those individuals, households and families not politically connected; and this has deep and undesired consequences in the management of urban areas in the end. In the Greater Harare urban (and peri-urban) landscape, the housing cooperatives have the power to control their members with respect to the contributions that each member can make in terms of finance and sweat equity (labor). Nevertheless, land as a resource remains a prerogative of the state, which the ZANU PF regime has controlled for a span of more than 30 years now. Housing cooperatives in Harare, as elsewhere in the country, try to identify with ZANU PF as a party identifying with conservativism enshrined in the existing laws (albeit the New Constitution that came about in 2013) and a party advocating for equity in the distribution of the land. Cooperatives have become a tool in which ZANU PF has re-asserted its influence and hegemony.
\end{abstract}

Keywords: Social capital, Manipulation, Control, Governance, State capacity, Homelessness, Housing land

\section{Background}

In sub-Saharan Africa, in the recent years, the decline of the welfare state in the provision of goods and services has seen the rise of housing cooperatives. These are a panacea to trying to curb the housing shortage in the urban centers. With reference to developments in Greater Harare in the post-2000 era, the purpose of this paper is to demonstrate how the role of housing cooperatives, meant to serve a technical problem of housing the homeless, has shifted from the mere technical agenda to the political one in which clientilism, patronage and manipulation are the manifestations. Greater Harare is a metropolitan region comprising Harare City (core), Chitungwiza, Norton, Epworth and Ruwa. Although these areas fall under disparate local authorities, they are essentially well connected. Their connectedness is in terms of spatiality, definition of labor and business markets, bulk water processing, as well as administration (mainly as Harare Metropolitan Province) mean that they strongly rely on each other.

There is paucity of data and case analyses on interplay of politics (particularly distributive politics) and housing development. This paper argues of a gap in knowledge in the understanding the political dynamics surrounding housing cooperatives today. In

(c) 2015 Chirisa et al. This article is distributed under the terms of the Creative Commons Attribution 4.0 International License (http:// creativecommons.org/licenses/by/4.0/), which permits unrestricted use, distribution, and reproduction in any medium, provided you give appropriate credit to the original author(s) and the source, provide a link to the Creative Commons license, and indicate if changes were made. 
addition, it argues for the subsumed political connectedness of state apparatus (largely in the form of government organizations) that emerges in the urban landscape of cities in Zimbabwe as responsible institutions seek to discharge their duties. Although, the government has failed in a major way, to deliver housing and other public goods, it still seeks to control and manipulate the people by seeking to woo support by 'distributing' land to the homeless especially in days just before elections.

We argue that the dominant resource defining the politicization of the housing cooperatives in Zimbabwe in the recent years has been the land. Land is the key resource that defines where homebuilders can locate the houses. In this paper, we explain how the ruling party, ZANU PF, which identifies with equity in the distribution of land, has through its various apparatus including the institution of the Ministry of Local Government, Publics Works and National Housing, has outwitted the MDC. The MDC has enjoyed urban votes since 2000. Despite this 'grace' of 'having the people', it has never taken full control of land as a resource that provides the habitation of these people. Besides the control of the land resource, ZANU PF, by design or default, identifies with the conservative agenda. In urban councils, the mayors (or chairpersons of council) together with the councilors are predominantly MDC yet the technocrats (appointed officials including town clerks, directors and various managers) identify with the conservative agenda as prescribed by the law and this tends to identify with the ZANU PF position.

\section{Theory: cooperatives as a political strategy; land as the tool for political favor and mass bait}

Literature shows how access to land and regime type (whether democratic or authoritarian) has become part of distributive politics and clientilism in the housing of urban low-income groups in recent years. The use of land as 'bait', through election promises is well-documented (for example, Boone 2013). After the elections, the poor residents become subject to precariousness because there is no security of tenure guaranteed to them. The poor often collaborate to mobilize resources instrumental for their self-help projects housing included. With reference to India, the Ministry of Agriculture (2009:iv) has argued that, "... the cooperative ability not only to help survival of the people but also of indirectly forcing the market to behave." The cooperative approach by poor households hinges of the needs and aspirations of the members, a factor which makes them strong (internally) (Shankar 2002). Nevertheless, where cooperatives have existed, the political processes obtaining in their context usually control their influence. They are often apron-tied to the agenda of government. As observed by Birchall (2003:ix), in the developing world, cooperatives "... have often been used as tools of development by governments that have not allowed them to become fully autonomous, member-owned businesses." Indeed, there may be internal democracy in a cooperative but the politicians tend to try to exploit this internal strength of the cooperative to their advantage hence the imminence of a clientistic logic. Vote buying, patronage, and machine politics often define this logic.

Clientilism fits within a variety of contexts. Hicken (2011:289) argues that “... in the face of economic development it often adapts and endures." It has a variety of outcomes including, sometimes subverting democracy and economic development, making it difficult for citizens to hold their elected official accountable hence tending to reinforce 
corruption in society. In light of this, Keefer (2007:813) characterizes younger democracies as "... more presidential, fractionalized, and affected by conflict. [There is usually] higher rent seeking and less government provision of goods and services of all kinds..." politicians often use goods like food, housing and medicines to buy votes from poor households. As put across by Kitschelt and Kselman (2012:2) clientelism “... involves an exchange in which politicians provide goods and services targeted to individual or small groups of voters, contingent on the latter reciprocating by surrendering their vote and contributing other services to the politicians' effort to win electoral office." Some politicians strive to built long term relationships with their 'clients' while others actually foster these exchanges into programs and projects (Auyero 1999). An observation by GansMorse, Mazzuca and Nichter (2013:1) is that, "During elections in many countries, clientelist parties (or political machines) distribute benefits to citizens in direct exchange for political support. Such parties compete not only [because] of policy platforms but also with material inducements given to individuals. These inducements often include food, medicine, and other forms of sustenance. In contexts where citizens are highly dependent on such handouts, including countries where the state fails to provide a social safety net, this pattern of machine politics can have particularly important consequences for democratic accountability and responsiveness."

Arguing about Zambia, Baldwin (2013:807) has analyzed that, “...the political opinions of patrons do not cause voters to vote against their political interests but to alter their expectations about the performance of candidates in delivering local public goods and services." Thus, voters are usually not coerced but make the choices they make willingly. The major determinant of the relationship hinges on the notion of reciprocity. Scott (1972:93) has posited that, "in the reciprocity demanded by the relationship each partner provides a service that is valued by the other." The patron may wield authority that the client may seek to tap into to access what he or she perceives as desirable. As to whether clientilism hooks on poverty, Stokes (2007:618) has argued that "poor people value a handout more highly than do wealthy people; hence, if one is going to hand out goodies, one will target the poor..." She further argues that "... poor people are risk averse and hence value more highly a bag of goodies in hand today than the promise of a redistributive public policy tomorrow..." (ibid). Indeed, for the poor, usually a bird at hand is worthy two in the bush. State institutions for public provision may be so incapacitated to provide public good and services. This provides a window through which ethnic, sectarian or cooperatives emerge to fill this gap. The leaders can transform (or politicians hijack) the cooperatives such that, in the words of Cammett and Issar (2010:417) “... the politicization of service provision ... can lead to uneven coverage or inequalities that further entrench societal divisions...."

With reference to sub-Saharan Africa, van de Walle (2009:3) has observed that, "competitive elections shorten the time horizons of governments who are more likely to maximize their short term gains from office." The politicians become 'innovative' in search for another chance in office. One way to do that is use of political favoritism (Kramon and Posner 2013). Land for housing has been used to present such favoritism. This is in keeping with Boone (2013:394)'s argument that, "When land and other assets are allocated via political hierarchies rather than through impersonal market relationships, voters, citizens, and business people lack the economic and political autonomy 
that is a sine qua non of liberal democracy. Those who do control access to livelihoods and assets have a source of political leverage over citizens that can be deployed to pressure or threaten voters in subtle ways." Specifically in Zimbabwe, land has been used as a good for subverting the landless voters to vote for ZANU PF. Boone (2013:382) explains, "In the electoral campaigns of 1990, 1996, and 2000, and 2002, 2004, and 2008, Mugabe used promises and plans of land acquisitions and state-sponsored resettlement to rev up political support and energize the party's rural supporters, and to secure the loyalty of ZANU-PF hardliners, the military, and rural constituencies through the manipulation of land grants." The rural land agenda later found its way into urban areas given the rising demand for housing land. The same land could be offered not merely to a few individuals but to those groups that could organize themselves into housing cooperatives.

\section{The concept of distributive politics}

Distributive politics is strongly connected to the theory of democratic accountability (Golden and Min 2013). If, as Harold Lasswell claimed, politics is all about "who gets what, when, how" (Lasswell 1936), then distributive politics, which involves allocations of government goods and services, lies at the heart of politics. Distributive policies involve taxes and transfers, and in particular the decisions about allocations of government goods and services to identifiable localities or groups (Golden and Min, 2013). The literature on distributive politics and political accountability indicate that political players use their control over government or public goods to allocate resources to their loyal supporters on the basis of political patronage.

Upon grouping themselves in a housing cooperative, the members normally set up a committee with a chairperson, vice chairperson, secretary, vice-secretary, a treasurer and committee members. The committee is a secretariat whose role is the administration of the matters that pertain to the cooperative and the housing project. Most cooperatives refer to this set up committee as 'the management'. It has to do the day-to-day running of the cooperative business including receiving membership subscriptions, and agreed levies and payments as well as attending to membership queries. When houses have been built, the management has the role of allocating the houses and to receive rentals from the housed members since the houses are not in individual ownership until all the members have been built. Moreover, the management has to, from time to time, call for meetings to explain to the members of recent developments and plans. Members outside the committee, which must hold its office in trusteeship of the entire membership can suggest, proposed and query strategies and methods employed by the management (committee) in the road to finishing the project. In very normative terms, the management is answerable to the membership. It must prepare books and accounts to explain income and expenditure as well as ensuring that the cooperative is kept in sound governance in keeping with the tenets of good corporate governance-trust, accountability, transparency, membership participation, to name these few.

Although the above is the ideal case, practice in the various housing cooperatives around the urban centers and in Harare in particular, has shown otherwise. In a number of situations, there has been fingering of certain of the leaders in gross abuse of funds, corruption, bribery and autocracy. The news of such bad cases has often triggered 
fear and mistrust that cooperatives are useful vehicles for housing delivery for the lowincome groups.

\section{The housing shortage problem in urban Zimbabwe}

There has ever been a housing problem ever since the colonial days. The colonial regimes managed to keep the problem concealed due to its harsh policies that ensured that the black Africans were kept in the rural areas unless they had a defined purpose in the city (specifically employment). A variety of statutes including pass and accommodations laws was crafted to control the numbers of Africans coming to cities. Black African women and children were not allowed in the cities. Men were main migrant laborers and could return to the rural areas at retirement. In the hotels and apartments that were created for the migrant labors, constant inspections were done so that those out of employment would be arrested forced back to the rural areas. There were a number of squatter camps, which emerged in the colonial days including Chirambahuyo at the edge of Harare. The colonial regime was ruthless on the perpetrators and illegal settlements were destroyed.

At independence in 1980, the ZANU PF government in powered set to remove the inhibitive laws a development that induced post-colonial mass urbanization. Critical to note is the homeownership scheme by the state in the early to late 1980s. The government might have been playing its role in distributive politics. In the colonial days, the bulk of houses for blacks was municipal housing in which the inhabitants got access through renting arrangements. The post-independence homeownership scheme was implemented to convert the rental housing to ownership so that the burden of maintenance would be transferred to individuals rather than the state. A number of low-income housing development schemes were initiated around the country. The major objective of these schemes was to address the housing problems which the urban residents were facing. Various partnerships were created between the state, local banks, finance houses, building societies and international organizations such as World Bank, CIDA, SIDA and USAID. As the groups of the homeless increased so was the pressure on the state to address their plight. A key example of this was the domestic workers in Malbereign in Harare who approached the city council and was eventually allocated land in Gillingham to construct the houses. This housing project is what is known as Tashinga Housing Cooperative.

State provision of housing deteriorated when the state embarked on economic liberalization in the 1990s in the program that was called the Economic Structural Adjustment Program (1991-1995). This has had a negative effect on the production of low-income housing in the urban centers. This development propelled low-income earners to pursue self-help housing schemes. There is always inherent politics of rural-land incorporation into urban; rural local authorities are not always willing to 'let go' their land. The process is also highly bureaucratic and cumbersome. Before the 'nationalization' of land with the fast-track land reform program of 2000, urban land incorporation involved serious dialoguing between the peri-urban farm owners who were not always willing to let go their land. Within the government, the process of negotiating for gazzetting of the land involved (and still involves) the different government ministries namely the ministry of land, the ministry of justice and the ministry of local government. These ministries 
always have different mandates, which tend to collide making the process clumsy and heavy. Meanwhile the pressure for housing land will be mounting and the housing backlog ballooning. Another handicap with the fast-track land reform program was its unpopularity with the western world, which predominantly had been the major donor in housing development. The international community blacklisted Zimbabwe and imposed sanctions on its leadership. The country also pulled out of the Commonwealth. These developments had negative bearings on the country's access to critical resources. Economic doldrums that characterized the nation starting from 1997 and reaching climax in 2008 further exacerbated the situation. Such a situation continued until the setting up of the Government of National Unity (GNU) between the three major political parties ZANU-PF, MDC-T and MDC-M in 2009. The GNU lasted 4 years (March 2009 to July 2013) when ZANU PF won with the majority and reset itself as the ruling party again. The period of the GNU while characterized by stabilization of the economy, did not bring much to housing development given the constant bickering between the political parties of the matters of constitution making, elections and indigenization of the economy.

Concisely, the housing shortage in Zimbabwe is a factor of increasing and uncontrolled urbanization entrenched in the lifting of colonial policies and legislations. In addition, the globalization agenda of economic reforms have meant the diminishing role of the state in the direct provisioning of housing (particularly for the low-income groups). The financial resources in the form of housing loans (with the pullout of the majority of international organizations that hitherto supported shelter development) and the shrinking of the mortgage market explain the lack of robust response to lowincome housing production. In the next section, we explain the factors leading to the rise of housing cooperatives in Greater Harare and how these cooperatives seek to define themselves and seek recognition both with ZANU PF and with state apparatus, particularly the local government through which housing is located.

\section{The rise of housing cooperatives in greater Harare}

In the early years of Zimbabwe's independence, there was a deliberate promotion by government of cooperatives for rural farming and housing construction. During these initial years, the state followed a socialist ideology. Specifically in the housing sector, the government promoted the idea of building brigades in which families were encouraged to pool their resources together to build houses for themselves after the local authorities would have availed land for them. Building brigades were to die a natural death because their idea was largely received by households extrinsically. There were issues of mismanagement of resources and internal conflicted with dispirited members. Later, workers in the private sectors began to complain to their employees about the need for decent accommodation. This was to see a number of work-based cooperatives emerging on the scene. Employers served as guarantors for loans obtained by the workers for servicing and developing their houses. As many people got retrenched due to ESAP, the workbased cooperative initiative began to lose its glamour and the now out-of-work lot had to device other means to get them housed. They had to 'hang around' the cities because cities always tend to have better and robust opportunities than rural areas. As they stayed in the cities, they needed shelter. 
Unlike in Latin America, Asia and many other parts of Africa where individuals, families and households can invade an open space and build then others can follow and cluster around, the non-tolerance of the state of such developments impelled many of these individuals, families and households to group together and negotiate for land. The state has always followed strict British planning laws and individuals, families and households that have always tried to circumvent the procedural laws with regards to land access. A critical and hallmark example was the Operation Restore Order (also referred to as Operation Murambatsvina) of May-June 2005 in which the individuals, families and households that had built their structures and started businesses suffered heavy losses. Most of them tried to have layout and building plans to justify why and where they were building. However, these plans had not been approved. There was destruction of over 700,000 businesses and housing structures with depicts a heavy loss to households. Ever since this negative development, many households have been careful in their approach to accessing land for housing and building. Due to council's inability to provide land for housing, individuals and families have resorted to the formation of co-operatives for them to have a collective voice. Once one group has succeeded in championing their cause and negotiating with the council, others have always followed suit to do the same.

Cooperators have found out that negotiating with local government officials for housing and without a patron that identifies with the party that identifies with equity in the distribution of land is very difficult. The councilors and mayors in Greater Harare are MDC (save for Epworth), they do not have 'legitimacy' (at least from the ZANU PF perspective) to speak about land. MDC argues that it has the people; ZANU PF argues that it has the land because it has advocated strongly for the equitable land distribution hence the land seizures and subsequent nationalization in 2000. Pressured by the woes of inadequate housing, the homeless urban residents have been cowed to identify with the ZANU PF land agenda. Because the local authorities can only attend to cooperatives and not individuals, the residents also form cooperatives. ZANU PF has been encouraged those who want land to build to get into the cooperatives. Once in the cooperatives, members must adhere to the requirements of the musangano (as ZANU PF is popularly referred to) and pledge their allegiance to vote for it without which the cooperatives risk losing their land. Such is the housing and the political landscape that has characterized Harare especially in the run-up to the July 31, 2013 Harmonized Elections in which ZANU PF won. Although, the party did not garner sufficient votes to get all the urban constituencies, it strongly believes that its membership base in the urban centers has significantly increased better than in the previous elections of 2000, 2002, 2005 and 2008. The party has used land as good for enticement of the urban homeless and housing cooperatives as a vehicle of achieving its goal of control of the urban citizens.

To ensure that the MDC grip on the urban residents is shattered, the politics of the centre and local (the center-local relations) has played out well for ZANU PF. Even in negotiating for ministries in the GNU, ZANU PF made it a point that it kept within its grip the Ministry of Local Government. This ministry, has since 2002 worked against the smooth running of MDC-led councils in the urban centers. It has ever made deliberate efforts to ensure that policies mooted by the MDC and meant to improve the physical urban landscape as well as the lives of the people are shattered. When the MDC councilors emerged in the urban scene, the hope of the populace was that this would not work 
corruptly as ZANU PF had done. Unfortunately, they fell victim to the same cancer that the Minister of Local Government then used as a weapon against them. He deliberately fired some of the councils (mayors and councilors). Just days to the 2013 Harmonized Elections the Minister announced as a directive debt relief on all residents owing councils in rates and levies. This, in a major way destabilized the smooth running of the urban centers. Such a move gave the minister and ZANU PF (where he belongs) applause from the people who were failing to settle their debts. However, those who had faithfully paid, suffered a loss and the fear is that a new culture of non-payment of bills has set into the detriment of good urban functionality. One reason why the minister deliberately allowed the local authorities to suffer was the fact that he said they had benefitted from his clemency of allowing them to benefit in salaries and wages at the expense of financing urban services, which the generality of the residents have not adequately accessed in the entire period of the GNU. The Urban Councils Act (Chapter 29:12) provides the minister of local authority with excessive and discretionary powers that he uses, manipulates and abuses as and when he feels like doing it.

For a long time, there has been unresponsiveness of the state and the legal framework and this has allowed the minister of local government to dictate autocratically what happens in the local authorities. Although the New Constitution (promulgated in May 2013) seeks to annul some of these powers, the new laws that go with the new supreme law of the land have not yet been put in place. Meanwhile, the same old and suppressive laws as it were continue to dictate the pace and nature of development in the country. Because ZANU PF is in control, it sees itself as not in a hurry to implement the provisions of the new constitution especially clauses like the devolution of power which it never was in support of during the constitution-making process (2009-2013). Such clauses would see the powers of the several ministers and the presidency undermined.

It is generally noted that more than 2,600 housing cooperatives have been registered countrywide, with more than 1,200 being allocated housing stands (Kachere 2014). In Harare, there has been massive development of housing cooperatives, many of which are regarded as illegal (Herald 2005). In order to demonstrate how distributive politics in urban Harare, data was collected from City of Harare's Housing and Community Services Department on the name of cooperative, number of stands allocated, state of development and membership which can be summarised in the following table (see Table 1). Just to demonstrate by a few housing cooperatives in Harare, as indicated in Table 1, those housing cooperatives connected to ZANU-PF have been allocated more sites to develop housing stands than those without political connectedness. This indicates that patronage and clientilism play a pivotal role in the allocation of land to housing cooperatives. In addition, the level of development and servicing among those housing cooperatives connected to ZANU-PF is advanced as compared to those which are not.

Surprisingly, in very recent times (June and July 2015), some of these cooperatives that bear the name of liberation war heroes and those who have political connection have been identified as illegal and have been demolished. These include Joseph Chinotimba in Glen View, Ivhu Rakauya in Aspindale, Chazezesa in Kuwadzana, Tashinga in Dzivarasekwa 2, Mujibha naChimbwido and Cain Nkala among others (Mawonde 2015).

In the next paragraphs, we explore how cooperatives work as a political strategy theoretically. 
Table 1 Charactering Some Harare's Housing Cooperatives

\begin{tabular}{|c|c|c|c|c|c|c|}
\hline $\begin{array}{l}\text { Name of } \\
\text { cooperative }\end{array}$ & $\begin{array}{l}\text { Established } \\
\text { (year) }\end{array}$ & $\begin{array}{l}\text { Party of } \\
\text { affiliation }\end{array}$ & Location & Membership & $\begin{array}{l}\text { No. of stands } \\
\text { allocated }\end{array}$ & $\begin{array}{l}\text { State of } \\
\text { development }\end{array}$ \\
\hline $\begin{array}{r}\text { Veterinary } \\
\text { Services }\end{array}$ & 2008 & None & Budiriro 3 & 126 & 126 & $\begin{array}{l}\text { No significant } \\
\text { progress has } \\
\text { been done }\end{array}$ \\
\hline Ndezvatenzi & 2014 & None & Glen View & 78 & No data & No data \\
\hline $\begin{array}{l}\text { Sangorinopawan- } \\
\text { eta }\end{array}$ & 2008 & None & Glen View & 12 & 12 & $\begin{array}{l}\text { Servicing nearly } \\
\text { complete }\end{array}$ \\
\hline Tembwe & 2008 & ZANU PF & Budiriro 4 & 185 & 185 & $\begin{array}{l}\text { Haphazard } \\
\text { development, } \\
\text { members } \\
\text { have erected } \\
\text { illegal struc- } \\
\text { tures }\end{array}$ \\
\hline $\begin{array}{l}\text { Rambaimakash- } \\
\text { inga }\end{array}$ & 2009 & ZANU PF & Budiriro 5 & 245 & 99 & $\begin{array}{l}\text { Servicing } \\
\text { complete. } 99 \\
\text { housing units } \\
\text { completed }\end{array}$ \\
\hline Gushungo & 2008 & ZANU PF & Mabvuku & 60 & 40 & $\begin{array}{l}\text { Servicing in } \\
\text { progress }\end{array}$ \\
\hline $\begin{array}{l}\text { Gushungo Robert } \\
\text { Mugabe }\end{array}$ & 2011 & ZANU PF & $\begin{array}{l}\text { Mabvuku/ } \\
\text { Tafara }\end{array}$ & 60 & 60 & $\begin{array}{l}\text { Water and } \\
\text { sewerage } \\
\text { reticulation } \\
\text { completed. } \\
\text { Houses at } \\
\text { various levels }\end{array}$ \\
\hline Holy Cross & 2011 & None & Budiriro 3 & 50 & 50 & $\begin{array}{l}\text { Servicing in } \\
\text { progress }\end{array}$ \\
\hline Pamuzinda & 2002 & ZANU PF & $\begin{array}{l}\text { Crowborough } \\
\text { North } \\
\text { Scheme }\end{array}$ & 21 & 15 & $\begin{array}{l}8 \text { units com- } \\
\text { plete }\end{array}$ \\
\hline Chombouta & 2008 & ZANU PF & Kuwadzana & 240 & 164 & $\begin{array}{l}\text { Servicing in } \\
\text { progress, } \\
\text { Issued with a } \\
\text { certificate of } \\
\text { parallel devel- } \\
\text { opment }\end{array}$ \\
\hline Kugarikakushinga & 1996 & ZANU PF & Mabvuku & 1,300 & 423 & $\begin{array}{l}423 \text { housing } \\
\text { units com- } \\
\text { pleted }\end{array}$ \\
\hline Hebert Chitepo & 2012 & ZANU PF & $\begin{array}{r}\text { Kuwadzana } \\
\text { Extension }\end{array}$ & 575 & 99 & $\begin{array}{l}\text { Servicing in } \\
\text { progress }\end{array}$ \\
\hline Mupedzahondo & 1998 & ZANU PF & Kuwadazana & 60 & 31 & $\begin{array}{l}31 \text { units com- } \\
\text { pleted }\end{array}$ \\
\hline Freedom & 2014 & ZANU PF & Glen View & No data & 44 & Unknown \\
\hline Kubatana & 2014 & None & Chadcombe & No data & 25 & Unknown \\
\hline $\begin{array}{l}\text { Empowered } \\
\text { Women }\end{array}$ & 2014 & ZANU PF & Kuwadzana & No Data & 12 & Unknown \\
\hline
\end{tabular}

Source: Department of Housing and Community Services (City of Harare) Records.

\section{Case studies of housing cooperatives in greater Harare}

In the case studies, we seek to proffer an outline of how distributive politics, clientilism and patronage take center stage in the context of housing co-operatives. The co-operative that have been formed due to the state's incapacity to provide public goods in the form of housing, indicate that the majority of them are linked to ZANU-PF. 


\section{Case 1: Leopold housing co-operative}

Leopold Takawira Housing Cooperative (LTHC) is a cooperative registered under the Co-operatives Act. Located along the High Glen Road across Old Marimba suburb, in Harare, LTHC was formed in 2004 by Innocent Pedzisai a nephew to the late liberation war hero Leopold Takawira. Innocent Pedzisai, the founder of the co-operative is currently the Legislator for Chirumanzu south representing ZANU PF in that constituency. This is a clear manifestation of the politics of housing. After its formation, the cooperative negotiated for land from the Ministry of Local Government, Public Works and National Housing. A piece of land was identified for them along Harare drive opposite Marimba Flats near the municipal water tanks, which saves areas like Rugare and Kambuzuma. The co-operative was given the offer letter for the land which was valued at US\$2 100,000. The land was subdivided and 814 residential stands were produced with an average stand size of $400 \mathrm{~m}^{2}$. According to one official of the co-operative membership to this project was open to everyone despite one's political affiliation. The main reason for this was that the cooperative wanted the project to be successful and as such one's income was the most important aspect that they considered to be a member of the co-operative. To join the co-op one would pay a joining fee of US\$500. A stand was then allocated. The monthly subscriptions have been fluctuating over the past years and ranged between $\$ 30$ in 2009 to $\$ 50$ in 2010-2012 and currently $\$ 100$. To date (end of 2014), the co-operative has managed to open gravel roads whilst water and sewer drawings are now in place and they expect to complete the basic infrastructure by end 2015.

No doubt, Leopold Takawira Housing Co-operative is linked to ZANU PF. The key informant interviewed has acknowledged this. Although the members claim to be from different political backgrounds sometimes, the cooperative mobilizes them into attending ZANU PF meetings. The key informant purports the cooperative does not force anyone to attend, this is unlike ZANU PF practice. This seems to contradict the usual ZANU PF practice, which always forces people to attend its rallies. Now, the co-operative is facing challenges when dealing with Harare city council. Some of these perceived challenges includes delays in the approval of water and sewer drawings and allegations of not following planning standards in the preparation of layout plans. Most of the challenges being faced by the co-operative emanate from the fact that they are among a group of co-operatives which are illegally occupying reserved open spaces in Harare. These co-operatives are motivated to do so because they are linked to Zanu PF which is the ruling part and most of the leaders in these co-operatives are war vetereans and as such there is an element of force when dealing with the local authority resulting in conflict. It was noted that in Mufakose, five housing co-operatives were granted authority by Zanu PF leadership to build on illegal space and among these are Joshua Nkomo Housing Co-operative, Leopold Takawira Housing Co-operative, Parkview Housing Pay Scheme. Beneficiaries of these co-operatives have vowed to continue building as they are pretty sure that they have got the support of their political leadership and the only action that the local authority can take is to legalise these developments.

All these unfolding scenarios in Harare are a clear testimony that land is being used as a tool by ZANU PF to mobilise support in urban areas and thus creating and enforcing the patron-client relationship. Whether it legal or illegal the client seems to be very 
confident that the Patron will not let them down as they have all the papers and this loyalty will most likely work in favour of the party come election times.

\section{Case study 2: Chombouta housing co-operative}

Chombouta Housing Co-operative was formed in 2004 and is based in Kuwadzana and it has got 240 members. In Kuwadzana, the co-operative managed to get a piece of land which has got 115 stands averaging $350 \mathrm{~m}^{2}$ in size. The co-operative purports to be open to all members of the public who are in need of a house in Harare. It uses the waiting list criteria for its members to benefit stands as and when they became available and it was not clear on the monthly subscriptions, which the members are supposed to pay. Contributions go towards purchasing the land as well as servicing but individuals will meet the costs of their houses. At the current project site the co-operative has managed to open roads, water and sewer reticulation are now in place. Since the cooperative is over subscribed against the available land the respondent pointed out that they are still looking for more land to accommodate those who have not yet benefited.

Coming to the origin and meaning of the co-operative name any Zimbabwean can tell that there is a lot of political connotation in it. Chombo means a weapon. This can be used to destroy or to build. On the other hand, [Ignatius] Chombo is the surname for the long standing Minister of Local Government, Public Works and National Housing from ZANU PF. In this case, one might be tempted to say he is the patron who supports the co-operative to acquire land in Harare. Despite the inappropriateness of the piece of land for residential development since it is rocky and hilly the co-operative managed to get the land. Recently in its bid to acquire more land, the co-operative has been the subject of debate between city of Harare Finance and Housing committees on the best possible use for a portion of land in Kuwadzana. According to planning requirements in Zimbabwe as guided by the Regional, Town and Country planning Act, a permit is required before any development or change of use of property is undertaken. A person wanting to carry out any operations or change of use can consult the local authority for guidance. Some applications are subject to the requirements that public notice must be given in respect of them and owners of adjacent properties must be notified. Therefore, in this case it is important that the case be brought to the attention of the public before a decision can be made. This is because the issue relates to a development which could in the opinion of the local planning authority, have an adverse effect or impact on the locality of the area in question. However, the truth is that most of these cases are not being brought to the attention of the public and decisions are being made without meaningful public participation.

\section{Discussion and policy implications}

Emerging from the foregoing paragraphs are a number of observations that have very critical underpinnings for policy and the practice of housing urban residents in Harare. We have argued strongly that housing cooperatives are a tool for clientilism. The urban residents that are homeless are the clients that approach identified elites, usually politicians, who then work hard to ensure that they get the land. Viewing housing cooperatives as a form of political clientilism calls into question many theoretical understandings of cooperatives including aspects of social capital and self-help. Access and control of land 
is major bait for manipulation and control of the urban homeless by regimes and political parties like ZANU PF. Because the urban low-income groups are poorly resourced, they see cooperatives as the vehicle through which they can have their voice heard to access land primarily and then to work together and mobilize critical resources needed to service the land (once they access it) and to put up their structures. In most cases, the average household ensures that it has a roof over its head and as a cooperative, they lobby for parallel development in which they are allowed to build the houses before they have put the road infrastructure and related services. In certain places, as demonstrated in the paper, the inhabitants have to devise coping strategies, which are costly. Housing cooperatives seem to promote the good governance ideal that is a contested issue. The other critical observation is that housing cooperatives in Greater Harare have tended to undermine access to public goods for those who are not politically connected. Overall, housing (and land for housing) in Africa should be understood as a form of distributive politics. In the Case of Greater Harare, the politics of who get what, where and how is quite popular, especially in the emerging housing cooperative areas such as Chombouta housing cooperative, Hopley, Southlea park, Epworth and Hatcliffe among others. These are places where the political elites identify pieces of vacant land and allocate them to their loyalists on a patronage basis. Those who are not politically connected find it very difficult to access land for housing. Land resources particularly in the peri-urban areas in vulnerable to voter opportunism by key political figures, especially those connected to the ruling party ZANU-PF. There are instances when politics assist in housing and when it does not.

\section{Conclusion}

The thrust of this paper has been to argue that the rise of housing cooperatives in Greater Harare, Zimbabwe is a direct response to the failure of the State and its apparatus to provision of public goods to the urban residents. Political elites and ZANU PF in particular have used this shortcoming as an advantage for them to practice some distributive politics over the scarce resource of urban land for housing. Access to housing land is a major asset that individuals seeking to build own homes have to find means to achieve. Although the MDC has prided itself as having the majority of urban votes, it non-capacity in controlling the urban land resource has worked out against it as ZANU PF has observed this gap, which it has capitalized to exploit. To get access to the people, the idea of housing cooperatives has been a welcome development to ZANU PF. In the Greater Harare urban (and peri-urban) landscape as elsewhere in the country, the internal dynamics of housing cooperatives provides them with critical power to control their members especially financial and labor contributions that aid social capital dynamics. We have demonstrated that, urban land in Harare (as many other urban centers in the countries) remains a prerogative of the state that the ZANU PF regime has controlled for more than three decades. Housing cooperatives in Greater Harare have tried to identify with ZANU PF hence has become a tool in which ZANU PF has re-asserted its influence and hegemony. The study has been critical in unraveling critical patterns of development embedded in cities which urban planning and other disciplines should never take for granted in their quest to bring up interventions. Indeed, urban planning is not in any way apolitical. Housing, in particular, is a 'political hot potato'. There is need for 
the designing of policies to ensure that households, individuals and families do not suffer development exclusion chiseled along political lines.

\section{Authors' contributions}

IC conceptualized the topic and did the literature review. NM designed the cases. EB revised the paper and worked on the comments from the reviewers before IC and NM revisited the whole manuscript. All authors read and approved the final manuscript.

\section{Acknowledgements}

We would like to thank the participants in our study as well as the key informants from City of Harare, the Ministry of Local Government, Public Works and National Housing. In addition, we thank the anonymous reviewers for their invaluable comments which helped us reshape our argument.

\section{Compliance with ethical guidelines}

Competing interests

The authors declare that they have no competing interests.

Received: 16 June 2015 Accepted: 31 July 2015

Published online: 07 August 2015

\section{References}

Abigail, Mawonde. 2015. Demolitions to render thousands homeless, Herald, 23 July 2015. Zimpapers: Harare.

Auyero, Javier. 1999. "From the client's point(s) of view": How poor people perceive and evaluate political clientelism. Theory and Society 28(2):297-334

Baldwin, Kate. 2013. Why vote with the chief? Political connections and public goods provision in Zambia. American Journal of Political Science 57(4): 794-809.

Birchall, Johnston. 2003. Rediscovering the cooperative advantage: Poverty reduction through self-help. Geneva: Cooperative Branch, International Labour Office.

Boone, Catherine (ed.). 2013. Zimbabwe in comparative perspective, Chapter 10. In Property and Political Order: Land Rights and the Structure of Politics in Africa, Cambridge: Cambridge University Press.

Cammett, Melani, and Issar Sukriti. 2010. Bricks and mortar clientelism: sectarianism and the logics of welfare allocation in Lebanon. World Politics 62(3): 381-421.

Eric, Kramon, and Daniel N. Posner. 2013. Who benefits from distributive politics? How the outcome one studies affects the answer one gets. Perspectives on Politics 11(2): 461-474.

Gans-Morse, Jordan, Sebastia'n, Mazzuca, and Simeon, Nichter. 2013.Varieties of Clientelism: Machine Politics during Elections. American Journal of Political Science 00(0): 1-18.

Golden, M., and B. Min. 2013. Distributive politics around the world. Annual Review of Political Science 16: 73-99.

Hicken, Allen. 2011. Clientelism. Annual Review of Political Science 14: 289-310.

Kachere, D. 2014. 2600 Housing Cooperatives registered. http://www.herald.co.zw/2-600-housing-co-operatives-registered/. Accessed 28 July 15).

Keefer, Philip. 2007. Clientelism, credibility, and the policy choices of young democracies. American Journal of Political Science 51(4): 804-821.

Kitschelt, Herbert, and Daniel, M., Kselman. 2012. Economic Development, Democratic Experience, and Political Parties' Linkage Strategies. Comparative Political Studies XX(X): 1-32.

Lasswell, H.D. 1936. Politics: Who Gets What, When, How. New York: McGraw-Hill.

Ministry of Agriculture. 2009. Report of the High Powered Committee on Cooperatives. New Delhi: Government of India.

Scott James, C. 1972. Patron-Client Politics and Political Change in Southeast Asia. The American Political Science Review 66(1): 91-113.

Shankar, R. 2002. How Cooperatives and their Apex Organizations can improve their Environment at the Local, National and International Levels. http://www.un.org/esa/socdev/social/papers/coop_shankar.pdf. Accessed 26 June 2014.

Stokes, Susan, C. 2007. Political Clientelism, Chapter 25 In Oxford Handbooks of Political Science, eds. Susan Stokes and Carles Boix, Oxford: Oxford University Press, 604-627.

The Herald. 2005. Illegal Housing Cooperatives named. http://www.herald.co.zw/index.php?id=44029\&pubd ate $=2005-06-03$. Accessed 28 July 15.

van de Walle, Nicolas. 2009. The Democratization of Political Clientelism in Sub-Saharan Africa. Paper Prepared for delivery at the 3rd European Conference on African Studies, Leipzig, Germany, June 4-7, 2009. 